\title{
Service Innovation in Industrial Contexts
}

Christian Kowalkowski

\section{Book Chapter}

N.B.: When citing this work, cite the original article.

Part of: Service Innovation : Novel Ways of Creating Value in Actor Systems, Marja Toivonen (eds), 2016, pp. 235-250. ISBN: 9784431549215 (print) and 9784431549222 (online).

Series: Translational Systems Sciences, ISSN: 2197-8832, No. 6

DOI: https:// doi.org/ 10.1007/978-4-431-54922-2_11

Copyright: Springer

Available at: Linköping University Institutional Repository (DiVA)

http:// urn.kb.se/resolve?urn=urn:nbn:se:liu:diva-142213 
Kowalkowski, Christian (2016), "Service Innovation in Industrial Contexts", pp. 235-249, in Service Innovation: Novel Ways of Creating Value in Actor Systems, Marja Toivonen (Ed.), Springer.

This is a so-called personal version (author's manuscript as accepted for publishing after the review process but prior to final layout and copy editing) of the article.

Readers are kindly asked to use the official publication in references.

\title{
Service innovation in industrial contexts
}

\section{Christian Kowalkowski ${ }^{1}$}

\begin{abstract}
Both academics and practitioners emphasize the importance for product firms of pursuing service innovation. Despite a strategic focus on service-led growth, however, many firms struggle to succeed with their service innovation initiatives. In order to increase our understanding of the nature of service innovation in product firms, this chapter discusses the specificities in, and dynamics of, service offerings, service processes, and business models in industrial contexts. First, it outlines key differences between new product development and new service development, and highlights issues like sales and delivery, which firms frequently fail to accomplish. While product development is generally 'back heavy' with many resources required for prototyping and technology development, service development is more 'front heavy' with more weight placed on market introduction, pilot testing, and securing the skills, systems, and infrastructures for sales and delivery. In terms of service offering innovation, a taxonomy based on service focus and revenue model is presented. In order to better understand service process innovation, Larsson and Bowen's (1989) service design typology is then revisited. Finally, common service business model archetypes are introduced and discussed.
\end{abstract}

Keywords: service innovation, business-to-business services, service classification, new service development, business model innovation

\footnotetext{
${ }^{1}$ Linköping University, Sweden, and Hanken School of Economics, Finland christian.kowalkowski@liu.se
} 


\section{Introduction}

'Everybody is in service. Often the less there seems, the more there is. The more technologically sophisticated the generic product (e.g., cars and computers), the more dependent are its sales on the quality and availability of its accompanying customer services (e.g., display rooms, delivery, repairs and maintenance, application aids, operator training, installation advice, warranty fulfillment). In this sense, General Motors is probably more service-intensive than manufacturing-intensive. Without its services its sales would shrivel' (Theodore Levitt, 1972, p. 42)

As Theodore Levitt pointed out over 40 years ago already, services are fundamental for the competitiveness of product firms. Since then, business researchers have noted the ever-growing importance of services in product industries. Consequently, major opportunities for service innovation reside in product firms as services become more central for their strategies and business models. In fact, as product firms have typically not pursued service innovation systematically, there is substantial improvement potential in the management and success of service innovation. The potential benefits of service-led growth are well documented, and rapid technological advances, such as cognitive computing (e.g., IBM) and Industrial Internet initiatives (e.g., General Electric), further spurs new service opportunities. Despite the identification of such business opportunities (Baines and Lightfoot 2013; Fischer et al. 2012), it has generally proven difficult to pursue service-led growth in productdominant settings. In addition, even with substantial growth in service innovation research (Carlborg et al. 2014), we still lack understanding of service innovation in product firms (Ostrom et al., 2015).

In engineering-driven companies and other product-centric firms, innovation still tends to be synonymous with new products or manufacturing processes. The old view of services as 'innovation laggards' prevails in many organizations, and service innovation often becomes a concern only once the new product is ready to launch. Consequently, product firms typically adopt what Coombs and Miles (2000) refer to as an assimilation or technologist perspective, 
which treats service activities as being similar to manufacturing activities. That is, methods and processes originally developed with manufacturing in mind are applied to services, which means that differences between services and manufacturing are suppressed and that unique service characteristics for that reason are undermined. On the other hand, a synthesis or integrative perspective to innovation has recently gained major ground among service innovation scholars (Carlborg et al. 2014). Synthesis-focused research aims to integrate insights from manufacturing-oriented and service-oriented research to advocate a unified perspective on innovation (Coombs and Miles 2000; Gallouj and Savona 2009).

However, in order to gain an in-depth understanding of service innovation in product firms, it is fruitful to adopt a demarcation perspective, which is the third main approach to service innovation. This research stream seeks to identify any possible particularity in the nature and organization of innovation in services, attempting to highlight the specificities in service offerings and service processes (Gallouj and Savona 2009). When discussing service innovation in product firms, a demarcation perspective is particularly useful. In manufacturing firms, new service development (NSD) and service innovation inevitably is compared with, and related to, the established bricks-and-mortar product development (NPD) processes and platforms. Hence, in order to gain an in-depth understanding of service innovation in product firms, it is advantageous to not only investigate the characteristics and nature of service innovation in general but also, whenever pertinent, to contrast it with product innovation.

Against this background, this chapter focuses on increasing our understanding of the nature of service innovation in product firms and industrial contexts. More specifically, I will discuss specificities in, and dynamics of, service offerings, service processes, and business models in product-dominant settings. First, however, I will briefly discuss how NSD differs from NPD. The arguments put forward are drawn on field studies of leading producers of capital goods, representing industries such as commercial vehicles, fluid handling and separation, industrial machinery, material handling, and mining equipment (see Kindström and Kowalkowski 2014, and Kowalkowski et al. 2015, for information on the methodologies of 
the research conducted). Common denominators between the firms are that they have strategically worked with service-led growth and extensively pursued service innovation activities. Nonetheless, the relative size and importance of the service business differed significantly, as did the scope of service innovation. The companyspecific differences, as well as industry-specific variance in terms of business network, customer characteristics, and industry lifecycle, enabled valuable insights into the dynamics of service innovation.

\section{New service development in product-centric firms}

In order to structure the development of new services, many companies blueprint existing NPD processes and methods. Alternatively, they modify the steps in these stage-gate processes to accommodate some of the service specificities they have experienced in previous NSD projects. Nonetheless, as Kindström and Kowalkowski (2009) report, product firms may fail to commercialize compelling service concepts due to this practice, which resonates with an assimilation perspective on service innovation. While the specific stages in the development process may not necessarily differ, the relative emphasis on each stage in terms of time and resources required generally does differ between NPD and NSD. While product development is generally 'back heavy' with much resources required for prototyping and technology development, service development is more 'front heavy' with more weight placed on market introduction, pilot testing, and securing the skills, systems, and infrastructures for sales and delivery. Figure 1 shows a schematic representation of these differences. While the differences may vary considerably between types of offerings, they are nonetheless essential to consider. 


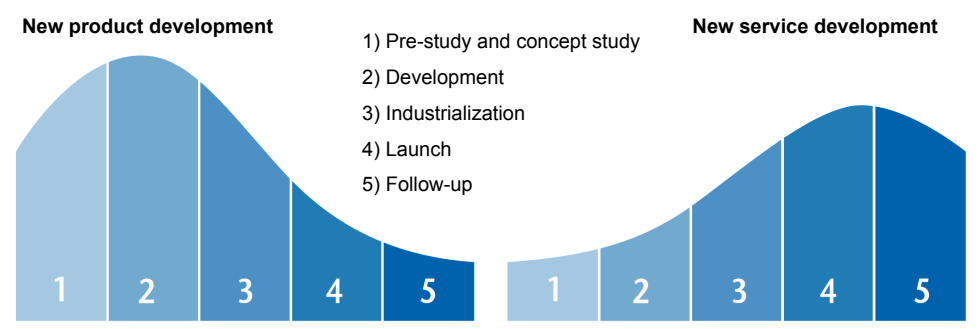

Figure 1. Differences in resource requirements between the stages of NPD and NSD (Kowalkowski and Kindström 2012, p. 112)

While the differences in resource requirements between the stages of NPD and NSD may vary considerably between types of offerings, they are nonetheless essential to consider for any company pursuing both product innovation and service innovation. Developing a first draft of a new service concept is rather straightforward compared to a new physical product prototype. The key challenge for many firms is instead to ensure that the sales and delivery organizations have adequate competence and commitment before launching the new service on the market (Kindström and Kowalkowski 2009). Table 1 shows important differences between product development and service development processes.

For product firms that successfully pursue product development, the changes needed for service development may prove challenging. Many firms have a shortage of resources and support for service development, and formal roles and experience within the organization are lacking. Successful service innovators generally have dedicated roles and units responsible for the development of new services. At the same time, they collaborate with product development teams to foster design-to-service capabilities (see also Ulaga and Reinartz 2011). Institutionalized collaboration between product and service development teams is also important as new product features and designs drive requirements for the service business, such as legal demands, product cost, new spare parts, and hardware and software design. 
Table 1. Differences between product development and service development

\begin{tabular}{|c|c|c|}
\hline Dimension & Product development & Service development \\
\hline Initiation & $\begin{array}{l}\text { Centrally initiated, structu- } \\
\text { red, technology driven: new } \\
\text { technology or new use of } \\
\text { existing technologies }\end{array}$ & $\begin{array}{l}\text { Locally initiated, close to cus- } \\
\text { tomers, ad hoc: New value crea- } \\
\text { tion potential identified }\end{array}$ \\
\hline $\begin{array}{l}\text { Strategic } \\
\text { perspective }\end{array}$ & Inside-out & Outside-in \\
\hline Key asset & Patents & Customer knowledge \\
\hline Development & $\begin{array}{l}\text { Closed process, involving } \\
\text { R\&D and production }\end{array}$ & $\begin{array}{l}\text { Open process, involving sales } \\
\text { companies and service organi- } \\
\text { zations }\end{array}$ \\
\hline $\begin{array}{l}\text { Tools and } \\
\text { methods }\end{array}$ & Stage-gate models & $\begin{array}{l}\text { Service blueprinting, service } \\
\text { engineering }\end{array}$ \\
\hline $\begin{array}{l}\text { Critical re- } \\
\text { sources }\end{array}$ & $\begin{array}{l}\text { Production facilities, com- } \\
\text { ponents, sub-systems, } \\
\text { supply chains }\end{array}$ & $\begin{array}{l}\text { Knowledge and skills, rela- } \\
\text { tionships and networks, inclu- } \\
\text { ding the resources of service } \\
\text { partners }\end{array}$ \\
\hline Stakeholders & $\begin{array}{l}\text { R\&D and other central units } \\
\text { and functions }\end{array}$ & $\begin{array}{l}\text { Local and central units, custo- } \\
\text { mers, partners/dealers }\end{array}$ \\
\hline $\begin{array}{l}\text { Marketing } \\
\text { and sales }\end{array}$ & $\begin{array}{l}\text { Market to (push): manage- } \\
\text { ment of customers and mar- } \\
\text { kets }\end{array}$ & $\begin{array}{l}\text { Market with (pull): collaborati- } \\
\text { on with customers and partners }\end{array}$ \\
\hline Result & $\begin{array}{l}\text { A tangible offering that is } \\
\text { easy to understand }\end{array}$ & $\begin{array}{l}\text { An intangible service that is dif- } \\
\text { ficult to visualize }\end{array}$ \\
\hline
\end{tabular}

One company to have developed a service-specific development process is Volvo Group, an 110,000 employee strong supplier of trucks, busses and construction equipment, which includes the Mack and Renault truck brands. As other multinational product firms, the company uses a global product development process which is based on a traditional stage-gate model. Since the development of software in many ways differs from the development of vehicles and engines, Volvo also has a specific development process for such projects. None of these processes were however regarded as adequate for service innovation. The structures and processes of product development were too rigid; service innovation requires a more flexible and iterative process with more active customer involvement in the development and launch phases, increased collaboration between functions and central and local units, 
and securing of resources and competences for sales and delivery. For example, the process has to consider that many innovative ideas emerge on the local level, in interaction with customers. Consequently, the company developed a global service development process. After a pre-study and several iterations, the first version was presented and the process was tested in real life for the first time in pilot projects. Based on feedback from these projects, the process and documentation was then revised and further refined. Emphasis is on the iterative characteristics of the process, and an interdisciplinary and holistic process with the means to systematically work with customer involvement and visualization are other cornerstones.

\subsection{Sales and delivery}

The creation of a service-savvy sales force is a key attribute in the practice of companies that succeed with their new services (Reinartz and Ulaga 2008). Typically, companies that fail with their NSD projects launch the service before they have ensured that the sales organization is ready to sell services (Kindström and Kowalkowski 2009). For instance, moving from a situation where many basic services are given away for free, in order to land the product deal to actually start to charge and actively sell services, can be a strenuous effort. Similarly, moving from selling basic services to more advanced ones, such as outcome-based contracts, implies changing the revenue logic and is associated with additional competence requirements and risks (e.g., Renault et al. 2010). In particular, if a consequence of the new service is that it sells its customers fewer products, the sales-related challenge can be major.

Overall, the sales cycle for advanced services and solutions are longer than for products, and the sales are more complex. While customer requirements are less well specified, more customer involvement and contact with more senior decision makers in the customer organization is required. As a result of these characteristics, more actors from both parties are usually involved in the sales process (Kindström et al. 2015; Ulaga and Loveland 2014). For service selling, the supplier takes the role of a 'customer problem solver', 
assisting the customer in solving problems and facilitating value creation, and the role of 'brand-value deliverer', which implies becoming a representative of the brand rather than the product. This requires that the sales force and the sales function have a comprehensive understanding of the service and its value potential for the specific customer. Similarly, the customer should be encouraged to play a more active role in formulating the problem and sharing the information with the supplier (Kindström et al. 2015).

Another key challenge for successful NSD is the delivery of the service once it is sold. Depending on service characteristics, different investments in technology and people are needed. For new products, given that the manufacturing is according to plan, the delivery process is rather straightforward. For services, however, delivery is often a long-term, interactive value-creation process in which the supplier has opportunities to learn about the customer operations (and vice versa) and receive input for how to improve the service. This is especially true if the service is continuous or repetitive, such as monitoring or contract-based service. Many companies underestimate the need to invest in the delivery infrastructure and people when developing the service, which potentially results in deteriorated service quality once the service is to be produced and delivered (Kindström and Kowalkowski 2009). Such problems are especially hard if the supplier has only recently moved into the service domain, as the credibility of the overall service initiative may be affected negatively. In addition, there may be negative spillover effects on the brand and reputation of the firm in general. On the other hand, other firms take a more proactive stance on service delivery, striving to find new opportunities to innovate not only the services but also the delivery processes. For example, in order to outline the methods for delivering services and interacting with customers, some firms have developed service scripts, service blueprints, and other techniques (Kindström et al. 2013).

For most product firms, the management of service delivery processes is not only an internal issue. Regardless of company or industry, external service partners (including dealers) are also involved in service delivery. Hence, delivery in many cases involves a continuous balancing of the comparative strengths and weaknesses of the internal service organization and the external service 
companies. This balancing act includes a control-versus-flexibility tradeoff, such as which services to provide in-house and which ones to outsource to external service firms (Kindström et al. 2013). While services related to the core product business are typically favorable to maintain in-house (Fang et al. 2008), there is a large variability in the types of organizational arrangements product firms have for their service delivery. Since the characteristics of the market channel and the firm's position in the business network differ between companies and markets, the possibilities to influence the organizational arrangements also vary considerably.

\section{$3 \quad$ New service offerings}

For many firms, innovation is still synonymous with new or significantly improved offerings. In terms of service innovation, even for product firms, there is a wider range of possible new options than there is for product innovation. In order to structure the service opportunities of the firm, taxonomies and other types of classification frameworks are useful tools. A common distinction, which is particularly relevant to product firms, is that between product-oriented services and process-oriented services (Mathieu 2001; Raddats and Kowalkowski 2014). Product-oriented services are related to the firm's (or others') products and focus on ensuring that they function as expected, for example through spare parts provision, reactive (breakdown) maintenance, preventive maintenance or reconditioning. The focus of process-oriented services is instead the customer's business processes in which the firm's products may -but do not have to - be included. Examples of process-oriented services include customer training, consulting, fleet management services, and outcome-based contracts.

Another important distinction, related to the revenue model of the service, is between input-based and output-based services (Ulaga and Reinartz 2011). Most services, whether product-oriented or process-oriented, are input based. Such services are sold with the promise to perform a deed, for example by charging per service hour, per course participant or training module, or per spare part sold. In practice, this means that the revenue model is not linked to 
customer value-in-use. On the other hand, providers of outputbased services are to various extents compensated on the basis of value-in-use. For instance, a customer may buy the service 'availability' or 'uptime' by paying a fixed monthly fee for the remote monitoring of a product or process. In other cases, services are even closer tied to customer value-in-use by focusing on the performance which availability enables. Performance services such as energy performance contracting can have the revenue mechanism linked to predefined value metrics such as achieved availability, production targets, and production outcome. If the value metrics are not achieved, the actual payment may be reduced while it may increase if the actual performance is above target. A taxonomy based on the two dimensions -service focus and revenue model - is presented in Figure 2 .

\begin{tabular}{|c|c|c|c|}
\hline $\begin{array}{l}\text { Customer } \\
\text { process }\end{array}$ & $\begin{array}{l}\text { Process Support } \\
\text { Services } \\
\text { E.g. engineering, } \\
\text { training, process } \\
\text { simulation }\end{array}$ & $\begin{array}{l}\text { Process } \\
\text { Availability } \\
\text { Services } \\
\text { E.g. rental plans, } \\
\text { fleet management, } \\
\text { service contracts }\end{array}$ & $\begin{array}{l}\text { Process } \\
\text { Performance } \\
\text { Services } \\
\text { E.g. gain-sharing and } \\
\text { outcome-based } \\
\text { contracts }\end{array}$ \\
\hline $\begin{array}{l}\text { Service } \\
\text { focus }\end{array}$ & $\begin{array}{l}\text { Product Lifecycle } \\
\text { Services } \\
\text { E.g. spare parts } \\
\text { provision, repair, } \\
\text { safety inspection }\end{array}$ & $\begin{array}{l}\text { Product } \\
\text { Availability } \\
\text { Services } \\
\text { E.g. preventive } \\
\text { maintenance, } \\
\text { remote monitoring }\end{array}$ & $\begin{array}{l}\text { Product } \\
\text { Performance } \\
\text { Services } \\
\text { E.g. reconditioning, } \\
\text { systems integration, } \\
\text { customized software }\end{array}$ \\
\hline Product & Input based & $\begin{array}{l}\text { Output based: } \\
\text { Availability }\end{array}$ & $\begin{array}{l}\text { Output based: } \\
\text { Performance }\end{array}$ \\
\hline
\end{tabular}

Figure 2. Taxonomy for service offerings (modified from Kindström and Kowalkowski 2014, p. 102)

In general, research on service innovation in product firms takes the perspective on service-led growth as a process, from basic product lifecycle services to more advanced availability services and potentially performance services (Matthyssens andVandenbempt, 2010; Oliva and Kallenberg, 2003). Nonetheless, reverse growth trajecto- 
ries are also evident, albeit on a smaller scale (Finne et al. 2013; Kowalkowski et al. 2015). From an innovation perspective, there is often inherent potential to utilize elements of process-oriented, outcome-based services and solutions, which are usually offered to large clients. As Kowalkowski et al. (2015) point out, firms can exploit the knowledge and experience gathered in these more complex, resource-demanding and relationship-intensive offerings, by downsizing them and standardizing various service elements according to service modularity thinking. In doing so, they are able to offer these recombinative innovations in a more cost-efficient manner to a larger and more heterogeneous customer base.

As illustrated in Table 1, local employees or customers often initiate new services, many times in an unplanned, ad hoc manner. This differs from NPD, which is typically centrally initiated, more structured, and driven by new technology or the new use of existing technologies. A key to successful service innovation is to understand the customers' businesses and needs, including involving customers in the development process, from idea generation (Matthing et al. 2004) to pilot testing and continuous feedback during usage (Oliveira and von Hippel 2011). By fostering customer relationships, companies become more knowledgeable about their operational and strategic needs. This knowledge can provide inputs to service innovation, for instance by differentiating between different types of customer needs (see Table 2). Depending on customer needs, companies can identify different opportunities for new types of services.

While much research focuses on the internal requirements for service innovation, such as critical resources and capabilities (Fischer et al. 2010; Kindström et al., 2013; Ulaga and Reinartz 2011), less literature is concerned with the overall service system. While value constellations with external actors can be vital for successful service innovation (Kowalkowski et al. 2013), many service initiatives can also be constrained by other network actors. For example, service companies and other intermediaries between the supplier and the customer may hinder the development of new services (Matthyssens and Vandenbempt 2008). 
Table 2. Customer needs and their implications for service innovation (modified from Avlonitis et al. 2014, p. 17)

\author{
Customer need \\ Implications for service innovation \\ Focus on core acti- Design services to seamlessly support and enhance the va- \\ vities lue of the customer's core activities \\ Restructuring costs Evaluate the option of retaining product ownership and of- \\ fering a leasing or rental service \\ Access to talent Adopt a customer centric focus and ability to offer exper- \\ tise adapted to customer needs \\ Reduce time to Offer engineering and R\&D capabilities as a service to the \\ market \\ Manage risk \\ customer and become a development partner \\ Consider how scale, specialization and expertise can be- \\ come a valuable source of mitigating business risk \\ Manage capacity \\ Increase flexibility of resources to mitigate fluctuations in \\ demand when customers procure services to manage capa- \\ city \\ Increase scalability \\ Increase volume flexibility and ramp up speed
}

Even if several options of disintermediation mechanisms are available to firms faced by undesired intermediaries in their market channels (Nordin et al. 2013), the potential risks for the individual company may be considered too large. One of the capital equipment manufacturers I studied developed a rental service on one of its most important markets. While the service offering resonated with the needs of several customers, the company nonetheless had to abruptly abandon its rental service initiative. The reason was rather simple: one of its largest customers was a national rental company that was buying the equipment to rent out to users. When the product firm entered the rental market it started to compete directly with the customer, and the customer responded by discontinuing all collaboration with the provider. Consequently, the company had two choices: either continue to market the service and lose one of its key customers or scrap the service and restore the customer relationship.

\title{
$4 \quad$ New service processes
}

In innovation and management research, process innovation is generally concerned with manufacturing processes (Adner and Le- 
vinthal 2001; Utterback and Abernathy 1975). For services, the production process is an open system (Eiglier and Langeard 1976), which is influenced not only because of endogenous factors but also due to the influence of customer participation and other exogenous factors (Grönroos and Ojasalo 2004; Larsson and Bowen 1989). In fact, customers can be regarded as 'partial' employees of the provider (Mills and Morris 1986) as they unequivocally are part of the social system in which the services are produced (Parsons 1956). Service production can take place through different production modes: either partly or fully in interaction between service provider and customer (i.e., service encounter), or in isolation from one another. Process innovation can involve alteration of any of the modes, or change the service process from one production mode to another, such as in the case of self-service innovation.

In order to facilitate the management of the design and coordination of services, Larsson and Bowen (1989) conceptualized a service process framework, in which different types of services require different processes and thus different relationships between the provider's front-office and back-office entities, and between the provider's and customer's employees. The first dimension in the framework concerns the customer disposition to participate, which is defined by the extent to which the customer plays an active role in supplying inputs to the service production process (labor, information, technology, time, etc.). Depending on the customer and the type of service offering and service system, the level of customer participation can differ significantly. The second dimension concerns the diversity of customer demand, which includes both the uniqueness of the entities to be served and the uniqueness of the desired outcome. Together, the two dimensions constitute a process framework with four distinct, interdependent patterns: pooled service design, sequential standardized service design, sequential customized service design, and reciprocal service design. Depending on service design, the degrees of coupling and the main locus of interdependence, which is the most complex area of coordination, differ.

Building on Thompson's (1967) interdependence typology, Larsson and Bowen (1989) align the interdependence patterns according to complexity: pooled $\Rightarrow$ sequential $\Rightarrow$ reciprocal. Pooled service design is dominated by standardized back-office operations 
whereas the front-office coordination of service interaction is limited, with tightly specified service scripts. It is the preferred service process design if both the diversity of demand and the customer disposition to participate are low. Remote monitoring and control is an example of a service that can be effectively managed through this kind of service design. Next, sequential standardized service design is customer dominated with tightly specified service scripts for front-office coordination. This service design is common if the customer disposition to participate is high while the diversity of demand is low. In those cases, the provider can offer the customers the technical infrastructure and training required for them to perform the service themselves. Examples are online spare parts ordering, surveillance, and basic maintenance work. Sequential customized service design, which is the third mode of interaction, is suitable if customers are less inclined to participate and the diversity of demand is high. In those cases, front/back-office coordination for service support is the main locus of interdependence, and emphasis is placed on adjusting customer orders and input to agreed performances. Traditional product-oriented industrial services, such as repair and maintenance, are generally designed in this manner. Finally, reciprocal service design relies on mutual customer/employee adjustments and large, loosely specified service scripts. Close interaction and dialogue is required for these types of services, which span from process support services, such as training and lifecycle analysis, to more complex problem-solving and process-oriented services. In addition, since service production is an open system with customer contact and participation, there is input uncertainty facing the system; the higher degree of customer involvement, the higher level of input uncertainty (Larsson and Bowen 1989).

As technological advances are enabling already existing services to be performed in new ways, hence changing the service process design, services do not necessarily fit into pre-defined service process interfaces in the original, static framework. For example, after formalization and standardization innovation (cf., Gallouj and Weinstein 1997), reciprocal services may no longer require the same degree of interaction and dialogue. As routines are established and more tasks can be automated, process designs can change from 
reciprocal to standardized. For example, a combination of local responsiveness (front office) with standardization and internal integration across organizational entities (back office) enable sequential customized design, whereas more consistent and less peopledependent local service processes facilitate sequential standardized design. In addition, new technologies and systems, such as automated, remote monitoring and control and software updates, can change the service design from sequential customized to pooled service design. This dynamic view on service process design and innovation is illustrated in Figure 3 (Kowalkowski 2008).

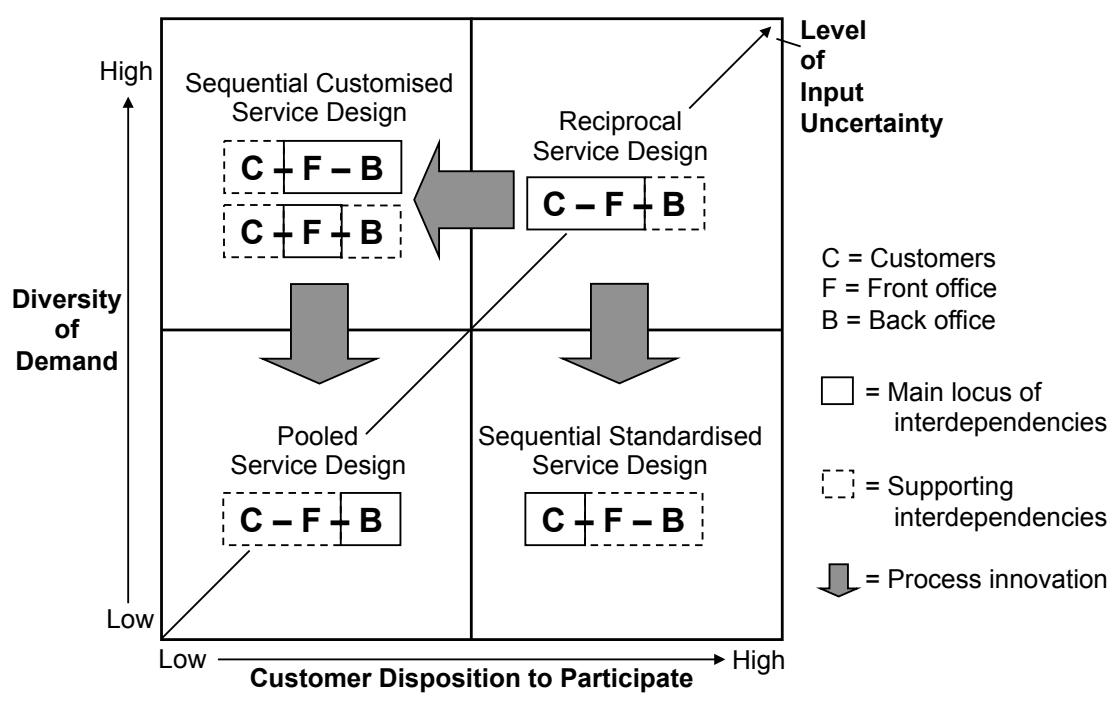

Figure 3. Dynamics of service process design (based on Larsson and Bowen 1989)

\section{$5 \quad$ Business model innovation and dynamics}

Business models may be conceptualized as depicting the rationale for how a firm creates, delivers, and captures value within a network of exchange partners (Massa and Tucci 2013). While business models may be decomposed into many different elements, such as Osterwalder and Pigneur's (2010) 9 point decomposition, business 
model innovation typically involves changing the offering, the revenue model(s) by which the firm will be paid for the offering, and the organizational processes (cf., Chesbrough and Rosenbloom 2002).

In literature on service-led growth in product firms, three business model archetypes (i.e., ideal examples) are common: equipment supplier; availability provider; and performance provider (Kowalkowski et al. 2015). Each archetype resonates with the categories of revenue models in Figure 1 (input-based, availabilitybased, and performance-based). They also correspond to Helander and Möller's (2007) three system-supplier roles which they link to the strategic position of the firm and to customer strategies (equipment supplier, availability provider and performance provider); and Windahl and Lakemond's (2010) categories of offerings (maintenance, operational, and performance offerings). The three archetypes are also analogous to Tukker's (2004) categories of productservice system models (product-oriented, use-oriented, and resultoriented).

An equipment supplier provides mainly product-oriented services aiming to protect and support the core product business. The services are input-based and standardized, and the degree of customer business process integration is low. Availability providers offer more complex services with use-oriented revenue models, and organize for higher degrees of business process integration. Finally, the performance provider business model implies even closer customer relationships and more advanced services for managing and operating customer processes where the customer frequently pays for actual, achieved results (Kowalkowski et al. 2015). When customers outsource service operations, such as the management of telecommunication networks or the energy maintenance of a production plant, firms acting as availability providers and performance providers are generally those that capture the business. 

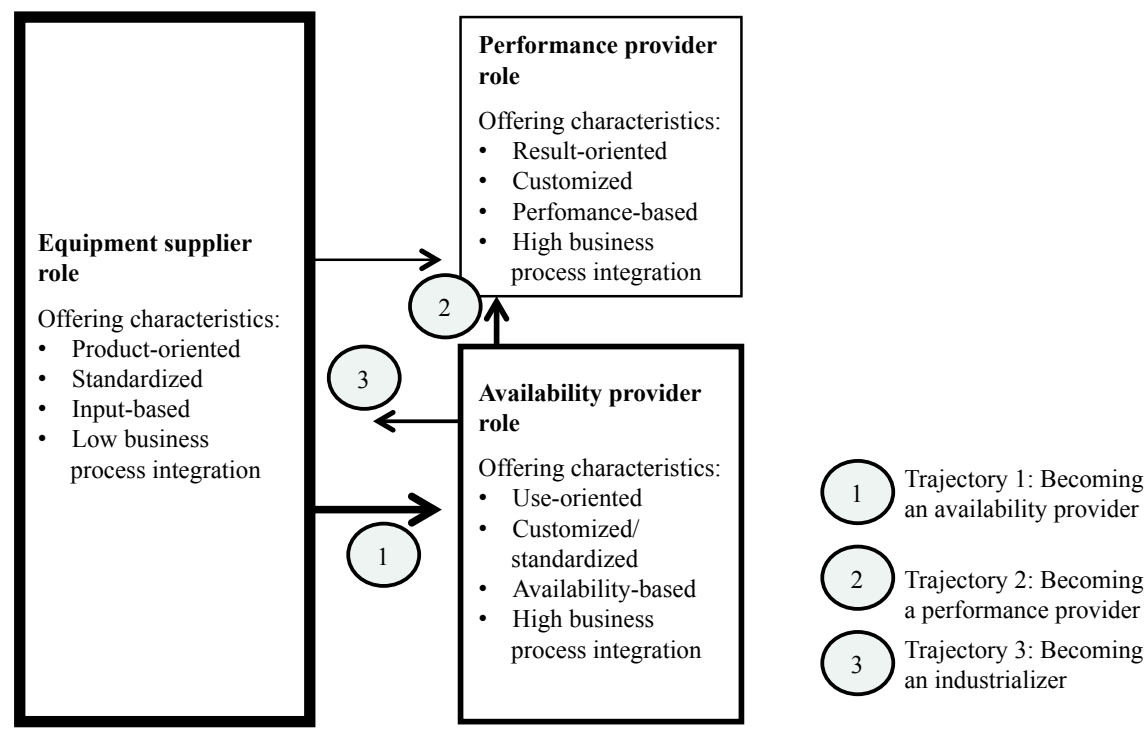

Figure 4. Business model innovation and dynamics (Kowalkowski et al. 2015 , p. 66)

Note: The thickness of the arrows and boxes only indicate that certain trajectories and roles are more prevalent than others and do not show exact proportions.

In terms of business models, product firms are generally transitioning from more traditional to more service-oriented and customercentric business models. This is illustrated in Figure 4 as 'becoming an availability provider' and 'becoming a performance provider'. However, a third service growth trajectory, which goes in the opposite direction, is sometimes also evident. 'Becoming an industrializer' can be understood as standardizing, and scaling down previously customized, output-based offerings in order to make them attractive and feasible to provide to a larger, more heterogeneous customer base. For example, service innovation opportunities can be identified by codifying and formalizing reciprocal services so that some of the service elements can be combined with other resources and offered to other customers in a repeatable and scalable manner. Availability and performance offerings might have been too extensive for the needs of more traditional equipment customers or unprofitable to offer due to their system scope, complexity, and 
risks. As Kowalkowski et al. (2015) show, this innovation path is however the most challenging to many firms. Prerequisites typically include long-term service experience, profound customer knowledge, product and process data, feedback loops and the ability to learn from existing solutions and lead users, and modularization competence. If these competences are lacking, they may constitute major hurdles for industrialization-type service innovation.

While product firms may be putting more relative emphasis on availability and performance business models, in practice firms often manage two or three of the archetypes simultaneously, rather than transitioning from a more traditional to a more service-centric business model only. Hence, firms typically work concurrently with different business models and depart from them to seize different service innovation opportunities.

\section{Conclusions}

Drawing on field research with product firms and business customers, this chapter outlines key differences between NSD and NPD, and issues of particular importance to product firms pursuing service innovation. Sales and delivery, which are often insufficiently addressed during service development, are specifically discussed. Based on a taxonomy of six combinations of service offerings and revenue models, opportunities for new service offerings are then discussed. Furthermore, departing in a typology of four service interdependence patterns, service process design is examined. Finally, three business model archetypes for service innovation in industrial contexts are presented. Familiarity with these different aspects of service innovation can provide valuable guidance to innovators and other organizational practitioners responsable for service development. 


\section{References}

Adner, R., \& Levinthal, D. 2001. Demand heterogeneity and technology evolution: implications for product and process innovation. Management Science, 47(5): 611-628.

Avlonitis, V., Frandsen, T., Hsuan, J., \& Karlsson, C. 2014. Driving competitiveness through servitization: a guide for practitioners. Copenhagen Business School: The CBS Competitiveness Platform.

Baines, T., \& Lightfoot, H. 2013. Made to Serve: How Manufacturers Can Compete through Servitization and Product Service Systems. Hoboken, NJ: John Wiley \& Sons.

Bowen, D. E., Siehl, C., \& Schneider, B. 1989. A Framework for Analyzing Customer Service Orientations in Manufacturing. Academy of Management Review, 14(1): 75-95.

Carlborg, P., Kindström, D., \& Kowalkowski, C. 2014. The evolution of service innovation research: a critical review and synthesis. Service Industries Journal, 34(5): 373-398.

Chesbrough, H., \& Rosenbloom, R. S. 2002. The role of the business model in capturing value from innovation: evidence from Xerox Corporation's technology spin-off companies. Industrial and Corporate Change, 11(3): 529-555.

Coombs, R., \& Miles, I. 2000. Innovation, Measurement and Services: The New Problematique. In J. S. Metcalfe, \& I. Miles (Eds.), Innovation systems in the service economy, measurement and case study analysis: 85-103. Boston, MA: Kluwer Academic.

Eiglier, P., \& Langeard, E. 1976. Principes de politique marketing pour les entreprises de services. L'Institute d'Administration des Enterprises, Universite d'Aix-Marseille, France.

Fang, E., Palmatier, R. W., \& Steenkamp, J. B. E. M. 2008. Effect of service transition strategies on firm value. Journal of Marketing, 72(5): 1-14.

Finne, M., Brax, S., \& Holmström, J. 2013. Reversed servitization paths: a case analysis of two manufacturers. Service Business, 7(4): 513-537. 
Fischer, T., Gebauer, H., \& Fleisch, E. 2012. Service Business Development: Strategies for Value Creation in Manufacturing Firms. Cambridge, UK: Cambridge University Press.

Fischer, T., Gebauer, H., Gregory, M., Ren, G., \& Fleisch, E. 2010. Exploitation or exploration in service business development? Insights from a dynamic capabilities perspective. Journal of Service Management, 21(5): 591-624.

Gallouj, F., \& Savona, M. 2009. Innovation in services: a review of the debate and a research agenda. Journal of Evolutionary Economics, 19(September): 149-172.

Gallouj, F., \& Weinstein, O. 1997. Innovation in services. Research Policy, 26(4/5): 537-556.

Grönroos, C., \& Ojasalo, K. 2004. Service productivity: Towards a conceptualization of the transformation of inputs into economic results in services. Journal of Business Research, 57: 414-423.

Helander, A., \& Möller, K. 2007. System supplier's customer strategy. Industrial Marketing Management, 36(8): 719-730.

Kindström, D., \& Kowalkowski, C. 2009. Development of industrial service offerings - A process framework. Journal of Service Management, 20(2): 156-172.

Kindström, D., \& Kowalkowski, C. 2014. Service innovation in product-centric firms: A multidimensional business model perspective. Journal of Business \& Industrial Marketing, 29(2): 96111.

Kindström, D., Kowalkowski, C., \& Alejandro, T. B. 2015. Adding services to product-based portfolios: an exploration of the implications for the sales function. Journal of Service Management, 26(3): 372-393.

Kindström, D., Kowalkowski, C., \& Sandberg, E. 2013. Enabling service innovation: A dynamic capabilities approach. Journal of Business Research, 66(8): 1063-1073.

Kowalkowski, C. 2008. Managing the Industrial Service Function. Doctoral dissertation, Linköping University, Linköping, Sweden. http://dx.doi.org/10.6084/m9.figshare.985584.

Kowalkowski, C., \& Kindström, D. 2012. Tjänster och helhetslösningar: nya affärsmodeller för konkurrenskraft. Malmö, Sweden: Liber. 
Kowalkowski, C., Windahl, C., Kindström, D., \& Gebauer, H. 2015. What service transition? Rethinking established assumptions about manufacturers' service-led growth strategies. Industrial Marketing Management, 45(2): 59-69.

Kowalkowski, C., Witell, L., \& Gustafsson, A. 2013. Any way goes: Identifying value constellations for service infusion in SMEs. Industrial Marketing Management, 42(1): 18-30.

Larsson, R., \& Bowen, D. E. 1989. Organization and Customer: Managing Design and Coordination of Services. Academy of Management Review, 14(2): 213-233.

Levitt, T. 1972. Production-line approach to service. Harvard Business Review, 50(5): 41-52.

Massa, L., \& Tucci, C. L. 2013. Business model innovation. In M. Dodgson, D. Gann, \& N. Phillips (Eds.), The Oxford Handbook of Innovation Management: 420-441. Oxford, UK: Oxford University Press.

Mathieu, V. 2001. Product services: from a service supporting the product to a service supporting the client. Journal of Business \& Industrial Marketing, 16(1): 39-61.

Matthing, J., Sanden, B., \& Edvardsson, B. 2004. New service development: learning from and with customers. International Journal of Service Industry Management, 15(5): 479-498.

Matthyssens, P., \& Vandenbempt, K. 2008. Moving from basic offerings to value-added solutions: Strategies, barriers and alignment. Industrial Marketing Management, 37(3): 316-328.

Matthyssens, P., \& Vandenbempt, K. 2010. Service addition as business market strategy: Identification of transition trajectories. Journal of Service Management, 21(5): 693-714.

Mills, P. K., \& Morris, J. H. 1986. Clients as "Partial" Employees of Service Organizations: Role Development in Client Participation. Academy of Management Review, 11(4): 726-735.

Nordin, F., Brozovic, D., \& Holmlund, M. 2013. Disintermediation mechanisms in industrial service channels: Mechanisms and Challenges. Journal of Business-to-Business Marketing, 20(4): 179-192.

Oliva, R., \& Kallenberg, R. 2003. Managing the transition from products to services. International Journal of Service Industry Management, 14(2): 160-172. 
Oliveira, P., \& von Hippel, E. 2011. Users as service innovators: The case of banking services. Research Policy, 40(6): 806-818.

Osterwalder, A., \& Pigneur, Y. 2010. Business model generation: a handbook for visionaries, game changers, and challengers: John Wiley \& Sons.

Ostrom, A. L., Parasuraman, A., Bowen, D. E., Patrício, L., Voss, C. A., \& Lemon, K. 2015. Service Research Priorities in a Rapidly Changing Context. Journal of Service Research, 18(2): 127-159.

Parsons, T. 1956. Suggestions for a Sociological Approach to the Theory of Organizations - I. Administrative Science Quarterly, 1(1): 63-85.

Raddats, C., \& Kowalkowski, C. 2014. A reconceptualization of manufacturers' service strategies. Journal of Business-toBusiness Marketing, 21(1): 19-34.

Reinartz, W., \& Ulaga, W. 2008. How to Sell Services MORE Profitably. Harvard Business Review, 86(5): 90-96.

Renault, C., Dalsace, F., \& Ulaga, W. 2010. Michelin fleet solutions-From selling tires to selling kilometers. ECCH Case Study.

Thompson, J. D. 1967. Organizations in action (First ed.). New York: McGraw-Hill.

Tukker, A. 2004. Eight types of product-service system: eight ways to sustainability? Experiences from SusProNet. Business strategy and the environment, 13(4): 246-260.

Ulaga, W., \& Loveland, J. M. 2014. Transitioning from product to service-led growth in manufacturing firms: Emergent challenges in selecting and managing the industrial sales force. Industrial Marketing Management, 43(1): 113-125.

Ulaga, W., \& Reinartz, W. 2011. Hybrid offerings: How manufacturing firms combine goods and services successfully. Journal of Marketing, 75(November): 5-23.

Utterback, J. M., \& Abernathy, W. J. 1975. A dynamic model of process and product innovation. Omega, 3(6): 639-656.

Windahl, C., \& Lakemond, N. 2010. Integrated solutions from a service-centered perspective: Applicability and limitations in the capital goods industry. Industrial Marketing Management, 39(8): 1278-1290. 